\title{
Przestępstwa gospodarcze z Kodeksu spółek handlowych w świetle danych statystycznych
}

\author{
PiOTR OCHMAN \\ ORCID: 0000-0001-5590-3299 \\ Katedra Kryminologii i Nauk o Bezpieczeństwie \\ Wydział Prawa, Administracji i Ekonomii Uniwersytetu Wrocławskiego
}

\section{Uwagi wprowadzające}

1. W dniu 15 września 2000 roku został uchwalony Kodeks spółek handlowych ${ }^{1}$ stanowiący fundamentalną regulację prawną $\mathrm{w}$ zakresie tworzenia, organizacji, funkcjonowania, rozwiązywania, łączenia, podziału i przekształcania spółek handlowych. Wejście w życie tej ustawy miało na celu wyczerpujące uregulowanie problematyki prawa spółek handlowych, zwłaszcza poprzez uporządkowanie regulacji prawa handlowego i jej rozdzielenie pomiędzy k.s.h. oraz ustawę z dnia 23 kwietnia 1964 roku - Kodeks cywilny ${ }^{2}$, przy jednoczesnym utrzymaniu dotychczasowych instytucji prawa handlowego oraz powiększeniu katalogu spółek, a także wyczerpującym uregulowaniu problematyki łączenia i podziału spółek ${ }^{3}$. W tytule V k.s.h. (art. 585-595) przewidziane zostały „Przepisy karne” określające odpowiedzialność „,uczestników spółek oraz członków

${ }^{1}$ Dz.U. Nr 94, poz. 1037 z późn. zm. (dalej: k.s.h.).

${ }^{2}$ Dz.U. z 2019 r. poz. 1145 z późn. zm. (dalej: k.c.).

${ }^{3}$ Rządowy projekt ustawy - Kodeks spółek handlowych, druk sejmowy nr 1687 (dalej: Projekt). 
ich organów, likwidatorów i ewentualnie innych osób"4. Przepisy te — jak stwierdzono w uzasadnieniu Projektu — w zasadzie bez zmian przejęły dotychczasowe unormowania rozporządzenia Prezydenta Rzeczypospolitej z dnia 27 czerwca 1934 roku — Kodeks handlowy ${ }^{5}$. Wskazana jednostka wewnętrznej systematyzacji k.s.h. określała następujące przestępstwa:

— działanie na szkodę spółki (art. 585 k.s.h.) ${ }^{6}$,

— niezgłoszenie wniosku o upadłość spółki (art. 586 k.s.h.) ${ }^{7}$,

- ogłaszanie albo przedstawianie nieprawdziwych danych dotyczących spółek kapitałowych (art. 587 k.s.h.) $)^{8}$,

- dopuszczanie do nabycia przez spółkę udziałów lub akcji własnych (art. 588 k.s.h.) ${ }^{9}$,

- dopuszczanie do wydania przez spółkę dokumentów na udziały lub prawa do zysków w spółce (art. 589 k.s.h.) ${ }^{10}$,

— fałszowanie dokumentów na walne zgromadzenie (art. 590 k.s.h.) ${ }^{11}$,

— posłużenie się sfałszowanymi dokumentami na walnym zgromadzeniu (art. 591 k.s.h.) ${ }^{12}$,

— bezprawne wydanie dokumentu akcji (art. 592 k.s.h.) ${ }^{13}$.

W art. 593 k.s.h., przepisie o charakterze procesowym, określono właściwość rzeczową sądu rejonowego w sprawach o określone powyżej przestępstwa ${ }^{14}$. Z kolei w przepisach art. 594 i 595 k.s.h. określono

${ }^{4}$ Ibidem.

5 Dz.U. poz. 502 z późn. zm. (dalej: k.h.).

${ }^{6}$ Odpowiednikami tego przestępstwa były czyny stypizowane w przepisach art. 300 i 482 k.h.

${ }^{7}$ Odpowiednikami tego przestępstwa były czyny stypizowane w przepisach art. 301 i 483 k.h.

${ }^{8}$ Odpowiednikami tego przestępstwa były czyny stypizowane w przepisach art 302 i 484 k.h.

${ }^{9}$ Odpowiednikami tego przestępstwa były czyny stypizowane w przepisach art. 303 i 487 k.h.

${ }^{10}$ Odpowiednikiem tego przestępstwa był czyn stypizowany w przepisie art. $304 \mathrm{k}$.h.

11 Odpowiednikiem tego przestępstwa był czyn stypizowany w przepisie art. 485 k.h.

12 Odpowiednikiem tego przestępstwa był czyn stypizowany w przepisie art. $486 \mathrm{k}$.h.

13 Odpowiednikiem tego przestępstwa był czyn stypizowany w przepisie art. $488 \mathrm{k} . \mathrm{h}$.

$14 \mathrm{~W}$ literaturze zasadnie wskazuje się, że przepis ten jest zbędny w świetle treści przepisu art. $25 \S 1$ ustawy z dnia 6 czerwca 1997 roku — Kodeks postępowania karnego (Dz.U. Nr 89, poz. 555 z późn. zm.). Zob. np. J. Giezek, P. Kardas, Przepisy karne kodeksu spótek handlowych, Kraków 2003, s. 656. 
czyny, które od strony konstrukcyjnej przypominają przestępstwa. Ich status w piśmiennictwie nie jest jednak jasny. Sporne są zwłaszcza takie zagadnienia, jak ${ }^{15}$ : charakter odpowiedzialności przewidzianej $\mathrm{w}$ tych przepisach (karna ${ }^{16}$, za wykroczenie ${ }^{17}$, inny rodzaj ${ }^{18}$ ), obiektywny charakter tej odpowiedzialności, jak również to, czy jej przesłanką jest wina.

2. W uchwale Sądu Najwyższego z dnia 27 sierpnia $2015 \mathrm{roku}^{19}$ wskazano, że przepis art. 594 k.s.h. reguluje odpowiedzialność cywilną za zaniechanie wykonania $\mathrm{z}$ winy umyślnej wymienionych $\mathrm{w}$ nim obowiązków. Wskazana konkluzja stanowiła rezultat przekonania Sądu Najwyższego, że

o charakterze normy prawnej decyduje kompleksowa analiza danego przepisu, w tym przypadku charakteru, wysokości i funkcji przewidzianej w nim sankcji, skutków prawnych, jakie ma wywołać, a także charakteru postępowania, w którym sankcja jest wymierzana. Ocena charakteru normy powinna także uwzględniać wnioski płynące z wykładni historycznej oraz systemowej.

Spośród argumentów przemawiających za takim charakterem odpowiedzialności w ocenie Sądu Najwyższego należy wymienić:

15 M. Bogomilska-Król, Zastosowanie konwencyjnych standardów praw do naruszeń penalizowanych w prawie krajowym niemajacych ściśle prawnokarnego charakteru - glosa do uchwaty Sąu Najwyższego z 27.08.2015 r., III CZP 62/15, dotyczacej naruszenia z art. 594 k.s.h., „Europejski Przegląd Sądowy” 2018, nr 8, s. 48.

16 M. Rogala, Spółki osobowe a przepisy karne kodeksu spółek handlowych, „Prawo Spółek" 2001, nr 1, s. 23; M. Bojarski, W. Radecki, Pozakodeksowe prawo karne. Komentarz, t. 2, Warszawa 2003, s. 202-203.

17 P. Kardas, Złożenie sadowi rejestrowemu listy wspólników niezgodnej z treścia wpisów w księdze udziałów, „Czasopismo Prawa Karnego i Nauk Penalnych” 2006, nr 1, s. 42 .

18 Określany przykładowo jako przewinienie (uchybienie) dyscyplinarne członków zarządu oraz likwidatorów — R. Zawłocki, Komentarz do art. 594, [w:] S. Sołtysiński et al., Kodeks spółek handlowych, t. 4. Łaczenie, podziat i przekształcanie spółek. Przepisy karne. Komentarz do artykułów 491-633, Warszawa 2012, s. 1498; A. Dermont, Przestępstwa gospodarcze w kodeksie spótek handlowych - wybrane zagadnienia, ,Prokuratura i Prawo" 2001, nr 10, s. 85; swoiste delikty prawa cywilnego o niezidentyfikowanym charakterze - J. Giezek, P. Kardas, op. cit., s. 671; czy też przymuszenie do wykonania obowiązków - J. Raglewski, R. Potrzeszcz, [w:] T. Siemiątkowski, R. Potrzeszcz, Kodeks spótek handlowych. Komentarz, t. 4, Warszawa 2011, s. 388.

19 Sygn. III CZP 62/15, OSNC 2016, nr 7-8, poz. 84. 
— zachowanie właściwości sądu rejestrowego w zakresie nakładania kary grzywny, który był również właściwy w tym zakresie pod rządami niemal bliźniaczych regulacji przepisów art. 306 i 490 k.h.;

— brak zamiaru ustawodawcy co do poszerzenia zakresu penalizacji względem przepisów statuujących odpowiedzialność karną pod rządami Kodeksu handlowego wynikający z treści uzasadnienia Projektu;

- umieszczenie przepisu art. 594 k.s.h. w rozdziale zatytułowanym „Odpowiedzialność karna”, jednakże z wyraźnym zastrzeżeniem (art. 593 k.s.h.), że przestępstwami są czyny wskazane w przepisach art. 586-592 k.s.h.;

— posłużenie się odmienną stylizacją w zakresie właściwości sądu rejestrowego określonej przepisem art. $594 \S 4$ k.s.h. aniżeli w przepisie art. 593 k.s.h.;

- zasady orzekania o grzywnie przez sąd rejestrowy w postępowaniu cywilnym z pominięciem zasad przewidzianych w kodeksie postępowania karnego;

— fakt, iż kara grzywny za przestępstwo jest „wymierzana”, podczas gdy grzywna stosowana w postępowaniu rejestrowym jest „nakładana”;

- wnioski płynące z wykładni systemowej a okoliczność, iż przepisy ustawy z dnia 28 października 2002 roku o odpowiedzialności podmiotów zbiorowych za czyny zabronione pod groźbą kary ${ }^{20} \mathrm{w}$ zakresie podstaw odpowiedzialności podmiotu kolektywnego odsyłają do przepisów art. 586-592 k.s.h. (art. 16 ust. 1 pkt 1 lit. f);

- założenie, aby w razie wątpliwości co do charakteru odpowiedzialności za dany czyn wyłączyć odpowiedzialność karną;

— wysokość grzywny przewidzianej w przepisie art. 594 k.s.h. przekraczająca granice zagrożenia ustalonego dla wykroczeń;

— brak możliwości określenia odpowiedzialności statuowanej przez przepis art. 594 k.s.h. jako odpowiedzialności dyscyplinarnej;

- okoliczność, iż odpowiedzialność przewidziana w przepisie art. 594 k.s.h. nie jest również odpowiedzialnością administracyjną, gdyż nie jest orzekana na podstawie decyzji administracyjnej podlegającej kontroli sądów administracyjnych.

20 Dz.U. z 2019 r. poz. 628 z późn. zm. 
Analizując wskazane argumenty przedstawione przez Sąd Najwyższy, nie sposób oprzeć się wrażeniu, że nie są one zbyt przekonujące ${ }^{21}$. Z uwagi na semantyczny kształt przepisu art. 594 k.s.h. (a także art. 595 k.s.h.) opowiedzenie się po którejkolwiek stronie sporu w przedmiocie charakteru odpowiedzialności nim statuowanej nie będzie mogło stanowić wystarczającego rozstrzygnięcia istniejących kontrowersji. Zasadnicze jednak znaczenie we wskazanym zakresie ma — jak się wydaje — nie precyzyjne ustalenie, czy do naruszeń wskazanych w powołanych przepisach mają zastosowanie zasady odpowiedzialności i zasady karania, określone w przepisach Kodeksu karnego, Kodeksu wykroczeń, czy regulacja Kodeksu cywilnego, lecz to, na podstawie jakich standardów należałoby rozstrzygać sprawy o naruszenie przepisów art. 594-595 k.s.h. ${ }^{22}$ Odpowiedzialność statuowana przez wskazane przepisy — z perspektywy jej funkcji — niewątpliwie może być kwalifikowana jako odpowiedzialność represyjna, wyrażająca się stworzeniem dla jej podmiotu znacznej dolegliwości ${ }^{23}$. Przyznanie funkcji represyjnej odpowiedzialności formalnie przynależnej do różnych dziedzin prawa niewątpliwie przekłada się na przesłanki materialne oraz zasady postępowania dotyczące tej odpowiedzialności ${ }^{24}$. Przeniesienie przytoczonych konkluzji na grunt zarysowanego sporu prowadzi w związku z tym do wniosku, że w odniesieniu do naruszeń określonych w przepisach art. 594 i 595 k.s.h. należy stosować standardy bliźniacze rozwiązaniom wykorzystywanym w sprawach karnych ${ }^{25}$, przy czym — z uwagi na to, że grzywna nakładana jest przez sąd rejestrowy, będący sądem gospodarczym — orzekanie następuje w trybie przepisów ustawy z dnia 17 listopada 1964 roku —

${ }^{21}$ M. Bogomilska-Król, op. cit., s. 48. Niektóre z powoływanych przez Sąd Najwyższy argumentów z powodzeniem mogą również stanowić uzasadnienie tezy przeciwnej.

22 Ibidem; M. Rodzynkiewicz, Komentarz do art. 594 k.s.h., [w:] Kodeks spótek handlowych, red. A. Opalski, t. 4. Laczenie, podziat i przekształcanie spótek. Przepisy karne. Komentarz. Art. 491-633, Warszawa 2016, nb 3; R. Zawłocki, Komentarz do art. 594..., s. 1499.

23 A. Błachnio-Parzych, Zbieg odpowiedzialności karnej i administracyjno-karnej jako zbieg reżimów odpowiedzialności represyjnej, Warszawa 2016, s. s. 42-50.

${ }^{24}$ Ibidem.

25 M. Bogomilska-Król, op. cit., s. 49, 51-52. 
Kodeks postępowania cywilnego ${ }^{26}$ oraz ustawy z dnia 20 sierpnia 1997 roku o Krajowym Rejestrze Sądowym ${ }^{27}$.

3. Kryminalizacja zachowań określonych w tytule V Kodeksu spółek handlowych od czasu wejścia w życie tego aktu prawnego ulegała wielu zmianom. Pierwsza grupa zmian miała charakter porządkowy i dotyczyła doprecyzowania ustawowych znamion przestępstw stypizowanych w k.s.h., a także ich dostosowania do zmienianych przepisów bazowych. Z dniem 15 stycznia 2004 roku, na mocy ustawy z dnia 12 grudnia 2003 roku o zmianie ustawy - Kodeks spółek handlowych oraz niektórych innych ustaw ${ }^{28}$, zmieniono przepis art. $587 \S 1$ k.s.h. poprzez rozszerzenie zakresu kryminalizacji na ogłaszanie albo przedstawianie danych dotyczących łączenia, podziału i przekształcania spółek, to jest określonych w tytule IV k.s.h. Wskazaną nowelizacją zmieniono również przepisy art. 590, 591 i 592 k.s.h. poprzez doprecyzowanie, iż odpowiednio karnoprawnie relewantne złożenie lub użyczenie innemu (art. 590 k.s.h.), posłużenie się (art. 591 k.s.h.) albo „wydanie” (art. 592 k.s.h.) ma dotyczyć nie „akcji”, lecz „dokumentu akcji”. Drugą nowelizacją, która dotknęła przepisów karnych k.s.h., była zmiana wprowadzona 5 grudnia 2009 roku ustawą z dnia 5 grudnia 2008 roku o zmianie ustawy — Kodeks spółek handlowych oraz ustawy o obrocie instrumentami finansowymi ${ }^{29}$, którą rozszerzono zakres kryminalizacji następujących przepisów:

— art. 590 k.s.h. poprzez dodanie punktów 3 i 4 dotyczących odpowiednio wystawiania fałszywego zaświadczenia o prawie uczestnictwa w walnym zgromadzeniu spółki publicznej oraz przekazywania lub udostępniania fałszywego wykazu akcjonariuszy uprawnionych do uczestnictwa w walnym zgromadzeniu spółki publicznej;

— art. 591 k.s.h. poprzez dodanie punktów 4 i 5 dotyczących posługiwania się fałszywym zaświadczeniem o prawie uczestnictwa w walnym zgromadzeniu spółki publicznej oraz fałszywymi instrukcjami do głosowania na walnym zgromadzeniu spółki publicznej.

\footnotetext{
26 Dz.U. z 2019 r. poz. 1460 z późn. zm.

27 Dz.U. z 2019 r. poz. 1500 z późn. zm.

28 Dz.U. Nr 229, poz. 2276.

29 Dz.U. Nr 13, poz. 69.
} 
Jedna z najistotniejszych nowelizacji przepisów karnych k.s.h. było uchylenie $^{30} \mathrm{z}$ dniem 13 lipca 2011 roku przez ustawę z dnia 9 czerwca 2011 roku o zmianie ustawy - Kodeks karny oraz niektórych innych ustaw ${ }^{31}$ przepisu art. 585 k.s.h. typizującego przestępstwo działania na szkodę spółki. Przyczyną takiego stanu rzeczy miały byćc ${ }^{32}$ : zmiana charakteru przestępstwa (na tak zwane przestępstwo konkretnego narażenia na niebezpieczeństwo zamiast dotychczasowego abstrakcyjnego narażenia na niebezpieczeństwo), włączenie problemu odpowiedzialności za działalność spółki w zakres penalizacji przepisu art. 296 k.k. oraz wprowadzenie wnioskowego trybu ścigania, chyba że pokrzywdzonym jest Skarb Państwa. Obecnie kryminalizacja zachowania zbliżonego do uprzednio ściganego na podstawie przepisu art. 585 k.s.h. zasadniczo wynika z przepisu art. $296 \S 1$ a k.k. ${ }^{33}$

Kolejną nowelizacją - merytorycznie związaną z uchyleniem przepisu art. 585 k.s.h. z dniem 30 kwietnia 2018 roku na podstawie ustawy $\mathrm{z}$ dnia 6 marca 2018 roku Przepisy wprowadzające ustawę - Prawo przedsiębiorców oraz inne ustawy dotyczące działalności gospodarczej ${ }^{34}$ — było dokonanie po kilku latach nieobowiązywania przepisu art. 585 k.s.h. korekty przepisu art. 593 k.s.h. przez uaktualnienie odwołania do przestępstw, w których właściwy jest sąd rejonowy, to jest z art. 586-592 k.s.h.

4. Aktualnie „Przepisy karne” Kodeksu spółek handlowych zawierają następujące przestępstwa:

— niezgłoszenie wniosku o upadłość spółki (art. 586 k.s.h.),

- ogłaszanie albo przedstawianie nieprawdziwych danych dotyczących spółek kapitałowych (art. 587 k.s.h.),

${ }^{30}$ Warto wskazać, że pierwotnie przepis art. 585 k.s.h. miał obowiązywać, lecz w zmienionej treści. Zob. przepis art. 26 pkt 3 ustawy z dnia 25 marca 2011 roku o ograniczaniu barier administracyjnych dla obywateli i przedsiębiorców (Dz.U. Nr 106, poz. 622).

31 Dz.U. Nr 133, poz. 767. Zob. R. Zawłocki, Nowe przestępstwo niegospodarności bezszkodowej z art. 296 \& la KK, „Monitor Prawniczy” 2011, nr 18, s. 965-966.

32 Biuletyn z posiedzenia Komisji Nadzwyczajnej do Spraw Zmian w Kodyfikacjach, Warszawa 2011, s. 5-6.

33 R. Zawłocki, Komentarz do art. 594, [w:] J. Bieniak, M. Bieniak, G. Nita-Jagielski, Kodeks spółek handlowych. Komentarz, Warszawa 2017, s. 1526.

34 Dz.U. poz. 650. 
- dopuszczanie do nabycia przez spółkę udziałów lub akcji własnych (art. 588 k.s.h.),

- dopuszczanie do wydania przez spółkę dokumentów na udziały lub prawa do zysków w spółce (art. 589 k.s.h.),

— fałszowanie dokumentów na walne zgromadzenie (art. 590 k.s.h.),

— posłużenie się sfałszowanymi dokumentami na walnym zgromadzeniu (art. 591 k.s.h.),

— bezprawne wydanie dokumentu akcji (art. 592 k.s.h.).

Wskazane przestępstwa nie są zagrożone szczególnie surowymi karami. Z perspektywy kryminologicznej można je zaliczyć raczej do tak zwanej drobnej przestępczości ${ }^{35}$. W przeważającej mierze z tytułu ich popełnienia może być zastosowana kara grzywny, kara ograniczenia wolności albo kara pozbawienia wolności do roku (art. 586 k.s.h., art. 587 $\S 2$ k.s.h., art. 590 k.s.h., art. 591 k.s.h., art. 592 k.s.h.). W dwóch wypadkach przestępstwa (art. 588 i 589 k.s.h.) zagrożone są karą grzywny, karą ograniczenia wolności albo karą pozbawienia wolności do sześciu miesięcy. W jednym natomiast przypadku przestępstwo (art. $587 \S 1$ k.s.h.) zagrożone jest karą grzywny, karą ograniczenia wolności albo karą pozbawienia wolności do lat dwóch.

5. Przestępstwa stypizowane $\mathrm{w}$ Kodeksie spółek handlowych to przestępstwa gospodarcze. Do ich istoty należy ochrona prawidłowości obrotu gospodarczego ${ }^{36}$ oraz bezpieczeństwa, stabilności i zaufania do podstawowych instytucji obrotu gospodarczego ${ }^{37}$. Omawiane przestępstwa mogą zostać zaliczone do grupy tak zwanych przestępstw gospodarczych ogólnorynkowych. Są nimi gospodarczo bezprawne zachowania naruszające interesy innych podmiotów gospodarczych, godzące w obrót gospodarczy, ze wskazaniem na naruszenie obowiązków lub uprawnień, które są charakterystyczne dla ogółu profesjonalnych uczest-

35 Zob. A. Zoll, ,,Drobna przestęczość” jako problem dogmatyki prawa karnego i polityki karnej, [w:] J. Czapska et al., Zasady procesu karnego wobec wyzwań wspótczesności. Księga pamiątkowa ku czci profesora Stanisława Waltosia, Warszawa 2002, s. $452,455$.

${ }^{36}$ R. Zawłocki, System Prawa Karnego, t. 9. Przestepstwa przeciwko mieniu i gospodarcze, Warszawa 2011, s. 435.

${ }^{37}$ P. Ochman, Ochrona działalności bankowej w prawie karnym gospodarczym. Przepisy karne ustaw bankowych, Warszawa 2011, s. 137-138. 
ników obrotu gospodarczego ${ }^{38}$. Warto przy tym wskazać, że typizacja zachowań przestępnych o znamionach wykazujących podobieństwo do określonych w Kodeksie spółek handlowych nie jest w pozakodeksowym prawie karnym gospodarczym odosobniona. W innych ustawach regulujących funkcjonowanie obrotu gospodarczego w aspekcie funkcjonowania podmiotów szczególnych (na przykład zakładów ubezpieczeń, spółdzielni) można zlokalizować przestępstwa o zbliżonych ustawowych znamionach dostosowanych jednak dziedzinowo do zakresu tych aktów prawnych. Przykładowo przestępstwo niezgłoszenia wniosku o upadłość stypizowane jest także w ustawie z dnia 16 września 1982 roku — Prawo spółdzielcze $^{39}$ (art. 267b), ustawie z dnia 11 września 2015 roku o działalności ubezpieczeniowej i reasekuracyjnej ${ }^{40}$ (art. 435 i 436), ustawie z dnia 4 marca 2005 roku o europejskim zgrupowaniu interesów gospodarczych i spółce europejskiej $^{41}$ (art. 128), ustawie z dnia 22 lipca 2006 roku o spółdzielni europejskiej ${ }^{42}$ (art. 108) czy też ustawie z dnia 4 października 2018 roku o spółdzielniach rolników ${ }^{43}$ (art. 18 ust. 1).

6. Przedmiotem artykułu jest analiza prawomocnych skazań osób dorosłych za przestępstwa stypizowane w Kodeksie spółek handlowych w latach 2001-2018. Przy czym w zakresie struktury kar orzekanych za te przestępstwa analiza ta będzie dotyczyć lat 2008-2018. Stanowiące przedmiot niniejszego omówienia dociekania czynione są na podstawie danych statystycznych zawartych w dwóch opracowaniach przygotowanych przez Wydział Statystycznej Informacji Zarządczej w Departamencie Strategii i Funduszy Europejskich Ministerstwa Sprawiedliwości - Prawomocne skazania osób dorostych $w$ latach 1946-2016 $6^{44}$ oraz Prawomocnie skazani dorośli wedlug rodzajów przestęstw i wymiaru

38 S. Żółtek, Prawo karne gospodarcze w aspekcie zasady subsydiarności, Warszawa 2009, s. 187-188.

39 Dz.U. z 2018 r. poz. 1285 z późn. zm.

40 Dz.U. z 2019 r. poz. 381 z późn. zm.

41 Dz.U. z 2018 r. poz. 2036 z późn. zm.

42 Dz.U. z 2018 r. poz. 2043 z późn. zm.

43 Dz.U. z 2018 r. poz. 2073 z późn. zm.

44 Prawomocne skazania osób dorostych w latach 1946-2016, Warszawa 2017, https://isws.ms.gov.pl/pl/baza-statystyczna/publikacje/download,2779,9.html (dostęp: 3.11.2019). 
kary ${ }^{45}$. Pomimo zgłaszanych problemów i wątpliwości związanych z treścią i interpretacją danych statystyk oficjalnych ${ }^{46}$, ze względu na metodologię zbierania danych, dbałość o poprawę jakości statystyk wymiaru sprawiedliwości, a także ich zasięg oraz powszechne wykorzystywanie ${ }^{47}$, dane te - przy świadomości dotyczącej obciążeń statystyk oficjalnych — należy uznać za przydatne do realizacji założonego celu.

\section{Prawomocne skazania osób dorosłych za przestępstwa z k.s.h.}

1. Przepisy Kodeksu spółek handlowych, w tym „Przepisy karne”, weszły w życie 1 stycznia 2001 roku. Te ostatnie miały swoje odpowiedniki w przepisach Kodeksu handlowego ${ }^{48}$. Mając to na uwadze, należy wskazać, że obraz statystyczny prawomocnych skazań osób dorosłych w latach 2001-2018 byłby niepełny bez uwzględnienia skazań, do których doszło we wskazanym okresie, za przestępstwa stypizowane w Kodeksie handlowym. Pomimo bowiem uchylenia przepisów karnych Kodeksu handlowego z dniem wejścia w życie Kodeksu spółek handlowych w świetle przepisu art. $4 \S 1$ Kodeksu karnego statuującego zasadę lex mitior retro agit do sprawców, którzy popełnili czyny zabronione stypizowane w przepisach Kodeksu handlowego, a co do których rozstrzyganie następowało po wejściu w życie Kodeksu spółek handlowych, zastosowanie mogą mieć odpowiednie przepisy karne Kodeksu handlowego.

2. Mając powyższe na uwadze, trzeba nadmienić, że obraz prawomocnych skazań osób dorosłych za przestępstwa stypizowane w k.s.h. w latach 2001-2018 (uwidocznione w tabeli 1) uzupełniono o prawo-

45 Prawomocnie skazani dorośli według rodzajów przestępstw i wymiaru kary, https:// isws.ms.gov.pl/pl/baza-statystyczna/opracowania-wieloletnie/download,2853,40.html (dostęp: 3.11.2019).

46 Zob. J. Błachut, Problemy związane z pomiarem przestępczości, Warszawa 2007, s. 5.1; zob. także E. Babbie, Podstawy badań społecznych, Warszawa 2013, s. 373-375.

47 Zob. np. T. Szymanowski, Zmiany w przestęczości $w$ Polsce $w$ okresie po odzyskaniu niepodległości oraz ewolucja polityki karnej $w$ tym okresie $w$ świetle danych statystycznych, „Palestra” 2018, nr 9, s. 13.

48 Zob. przyp. 5-13. 
mocne skazania osób dorosłych za przestępstwa stypizowane w Kodeksie handlowym (przedstawione w tabeli 2). Ze względu na to, że po 2011 roku skazań za przestępstwa stypizowane w Kodeksie handlowym nie odnotowano, tabela 2 obejmuje lata 2001-2011.

Tabela 1. Prawomocne skazania osób dorosłych za przestępstwa stypizowane w k.s.h. w latach 2001-2018

\begin{tabular}{|c|c|c|c|c|c|c|c|c|c|}
\hline & 2001 & 2002 & 2003 & 2004 & 2005 & 2006 & 2007 & 2008 & 2009 \\
\hline Art. $585 \S 1$ k.s.h. & 4 & 6 & 15 & 23 & 29 & 28 & 24 & 40 & 39 \\
\hline Art. $585 \S 2$ k.s.h. & 0 & 0 & 1 & 0 & 0 & 2 & 0 & 3 & 2 \\
\hline Art. 586 k.s.h. & 1 & 17 & 29 & 43 & 61 & 56 & 45 & 78 & 59 \\
\hline Art. $587 \S 1$ k.s.h. & 1 & 9 & 3 & 5 & 2 & 2 & 4 & 3 & 3 \\
\hline Art. $587 \S 2$ k.s.h. & 0 & 1 & 1 & 0 & 0 & 0 & 0 & 1 & 0 \\
\hline Art. 591 pkt 2 k.s.h. & 0 & 0 & 0 & 0 & 0 & 0 & 0 & 0 & 0 \\
\hline \multirow[t]{2}{*}{ Ogółem } & 6 & 33 & 49 & 71 & 92 & 88 & 73 & 125 & 103 \\
\hline & 2010 & 2011 & 2012 & 2013 & 2014 & 2015 & 2016 & 2017 & 2018 \\
\hline Art. $585 \S 1$ k.s.h. & 32 & 11 & 1 & 1 & 0 & 0 & 0 & 0 & 0 \\
\hline Art. $585 \S 2$ k.s.h. & 0 & 0 & 1 & 0 & 0 & 0 & 0 & 0 & 0 \\
\hline Art. 586 k.s.h. & 45 & 56 & 53 & 53 & 80 & 74 & 67 & 80 & 65 \\
\hline Art. $587 \S 1$ k.s.h. & 6 & 1 & 0 & 2 & 2 & 11 & 2 & 3 & 1 \\
\hline Art. $587 \S 2$ k.s.h. & 3 & 0 & 0 & 0 & 0 & 0 & 0 & 0 & 0 \\
\hline Art. 591 pkt 2 k.s.h. & 0 & 0 & 0 & 0 & 0 & 2 & 0 & 0 & 0 \\
\hline Ogółem & 86 & 68 & 55 & 56 & 82 & 87 & 69 & 83 & 66 \\
\hline
\end{tabular}

Źródło: opracowanie własne.

Prawomocne skazania osób dorosłych za przestępstwa stypizowane w Kodeksie spółek handlowych w latach 2001-2018 należały do rzadkości. W 2001 roku, to jest w pierwszym roku obowiązywania „Przepisów karnych” Kodeksu spółek handlowych, odnotowano ogółem 6 skazań, natomiast najwięcej, bo 125 skazań — w roku 2008. Po zsumowaniu prawomocnych skazań osób dorosłych za przestępstwa stypizowane w k.s.h. oraz k.h. w latach 2001-2018 okazuje się, że najmniej skazań odnotowano w 2001 roku (45), najwięcej natomiast w 2008 (130). 
Tabela 2. Prawomocne skazania osób dorosłych za przestępstwa stypizowane w k.h. w latach 2001-2011

\begin{tabular}{|c|c|c|c|c|c|c|c|c|c|c|c|}
\hline & 2001 & 2002 & 2003 & 2004 & 2005 & 2006 & 2007 & 2008 & 2009 & 2010 & 2011 \\
\hline Art. $300 \S 1$ k.h. & 15 & 9 & 3 & 5 & 6 & 7 & 0 & 2 & 3 & 1 & 1 \\
\hline Art. $300 \S 2$ k.h. & 0 & 0 & 1 & 0 & 0 & 0 & 0 & 0 & 0 & 0 & 0 \\
\hline Art. 301 k.h. & 19 & 7 & 5 & 2 & 4 & 2 & 0 & 0 & 2 & 0 & 0 \\
\hline Art. $302 \S 2$ k.h. & 0 & 0 & 0 & 1 & 0 & 0 & 0 & 0 & 0 & 0 & 0 \\
\hline Art. $482 \S 1$ k.h. & 3 & 1 & 1 & 1 & 0 & 3 & 0 & 3 & 0 & 0 & 0 \\
\hline Art. $482 \S 2$ k.h. & 0 & 0 & 0 & 0 & 1 & 0 & 0 & 0 & 0 & 1 & 0 \\
\hline Art. 483 k.h. & 2 & 0 & 1 & 1 & 0 & 0 & 0 & 0 & 0 & 0 & 0 \\
\hline Art. $484 \S 1$ k.h. & 0 & 2 & 0 & 0 & 0 & 0 & 0 & 0 & 0 & 0 & 0 \\
\hline Art. $484 \S 2$ k.h. & 0 & 0 & 0 & 0 & 3 & 0 & 0 & 0 & 0 & 0 & 0 \\
\hline Ogółem & 39 & 19 & 11 & 10 & 14 & 12 & 0 & 5 & 5 & 2 & 1 \\
\hline
\end{tabular}

Źródło: opracowanie własne.

Po pierwszym okresie obowiązywania Kodeksu spółek handlowych (2001-2004) liczba prawomocnych skazań w latach 2005-2009 ustabilizowała się na poziomie około 100 rocznie (wyjątek stanowił rok 2007, kiedy było ich 73). Następnie wskutek uchylenia przepisu art. 585 k.s.h. liczba ta w latach 2011-2013 zmalała do 56 skazań. Z kolei od 2014 roku odnotowuje się rocznie około 60-80 skazań za przestępstwa stypizowane w k.s.h. Warto wskazać, że nie wszystkie z przestępstw stypizowanych w k.s.h. występowały w praktyce. Były to przede wszystkim przestępstwa określone w przepisach art. 585 k.s.h. (art. 300 i 482 k.h.) — działanie na szkodę spółki, art. 586 k.s.h. (art. 301 i 483 k.h.) — niezgłoszenie wniosku o upadłość — oraz art. 587 k.s.h. (art. 302 i 484 k.h.) - ogłaszanie albo przedstawianie nieprawdziwych danych. Dwukrotnie natomiast (w 2015 roku) doszło do skazań za przestępstwo z art. 591 pkt 2 k.s.h. - posłużenie się cudzym dokumentem akcji bez zgody właściciela. Spośród wskazanych przestępstw stypizowanych w Kodeksie spółek handlowych najczęściej do skazań dochodziło za przestępstwo niezgłoszenia wniosku o upadłość (art. 586 k.s.h., względnie art. 301 i 483 k.h.), działania na szkodę spółki (art. 585 k.s.h., względnie art. 300 i 482 k.h.) oraz ogłaszania albo przedstawiania nieprawdziwych danych (art. 587 k.s.h., względnie art. 302 i 484 k.h.). 
3. Zaprezentowane dane zestawiono także z prawomocnymi skazaniami osób dorosłych ogółem we wskazanym okresie, co przedstawiono na wykresie 1 .

W kolumnach uwidoczniono liczbę prawomocnych skazań za przestępstwa ogółem, natomiast na wykresie liniowym — prawomocne ska-

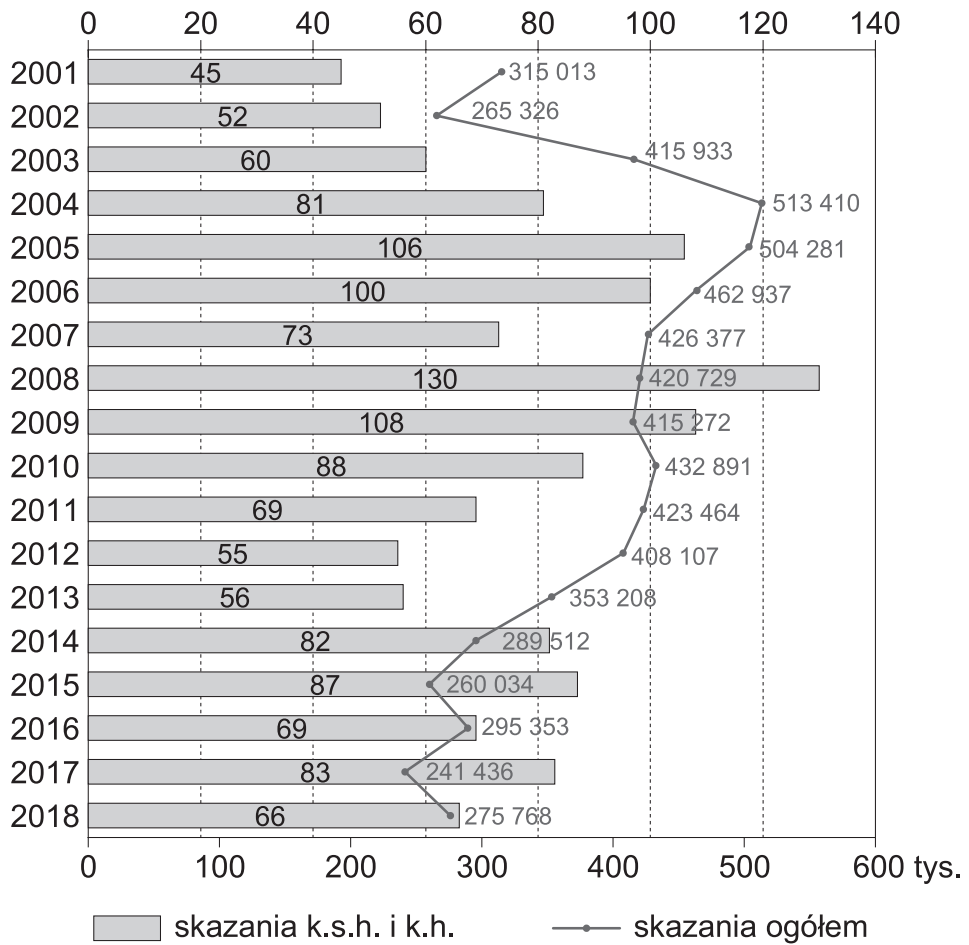

Wykres 1. Dynamika prawomocnych skazań osób dorosłych za przestępstwa stypizowane w k.s.h. i k.h. na tle skazań ogółem w latach 2001-2018

Źródło: opracowanie własne.

zania za przestępstwa stypizowane w k.s.h. i k.h. Jak można zauważyć, liczba skazań za przestępstwa z k.s.h. i k.h. w świetle skazań ogółem jest praktycznie znikoma (od 0,014\% w 2001 roku do 0,041\% w 2008 roku). Stanowi to szerszą tendencję w zakresie karania za pozakodeksowe przestępstwa gospodarcze, które w praktyce organów ścigania oraz organów 
wymiaru sprawiedliwości pojawiają się stosunkowo rzadko (dominacja kodeksowych przestępstw gospodarczych). Może to prowadzić do wniosku o konieczności uchylenia „Przepisów karnych” Kodeksu spółek handlowych ${ }^{49}$. Przyczyny takiego obrazu statystycznego przestępstw z Kodeksu spółek handlowych mogą być jednak również związane z niską świadomością społeczną istnienia czynów karalnych, brakiem zaufania do sformalizowanych agend kontroli społecznej czy też po prostu oportunizmem organów ścigania ${ }^{50}$. Warto bowiem wskazać, że przykładowo w roku 2017 istniały w Polsce 537273 spółki prawa handlowego ${ }^{51}$, z czego 12044 stanowiły spółki akcyjne i 451863 spółki z ograniczoną odpowiedzialnością ${ }^{52}$, dlatego też przy tej liczbie podmiotów, nawet przyjmując, że część z nich nie prowadzi aktywnej działalności, tak niska liczba wykrywanych, a następnie osądzanych patologii stanowiących przestępstwa gospodarcze może świadczyć o występowaniu ciemnej liczby tych przestępstw.

4. Ze względu na to, że — jak już wspomniano — szczegółowymi danymi w zakresie kar orzekanych za przestępstwa z k.s.h. dysponowano w odniesieniu do lat 2008-2018, dalsze rozważania w zakresie kar orzekanych za przestępstwa stypizowane w k.s.h. będą dotyczyły tego okresu.

Wskazana liczba kar orzekanych wobec prawomocnie skazanych osób dorosłych za przestępstwa stypizowane w k.s.h. w latach 2008-2018 nie pokrywa się jednak z liczbą prawomocnych skazań za te przestępstwa w omawianym okresie (tabela 1). Wynika to z faktu, że w pojedynczych przypadkach prawomocnych skazań osób dorosłych za przestępstwa stypizowane w k.s.h. poprzestawano na orzeczeniu samoistnego środka karnego. Taki stan rzeczy wystąpił w latach 2008 i 2009, kiedy to wobec sprawców przestępstw z art. 586 k.s.h. odpowiednio w 1 i 3 przypadkach orzeczono świadczenie pieniężne jako samoistny środek karny.

Analiza struktury kar orzekanych w latach 2008-2018 prowadzi do wniosku, iż dochodzi do zmian jakościowych w tym zakresie. Podczas

49 Zob. R. Zawłocki, Czy przepisy karne w Kodeksie spótek handlowych sa potrzebne, „Monitor Prawa Handlowego” 2013, nr 1, s. 5-11.

50 Por. J. Błachut, op. cit., s. 5.2.

51 Rocznik Statystyczny Rzeczypospolitej Polskiej, Warszawa 2018, s. 734. Liczba ta dotyczy podmiotów zarejestrowanych w rejestrze REGON.

52 Ibidem, s. 737. 


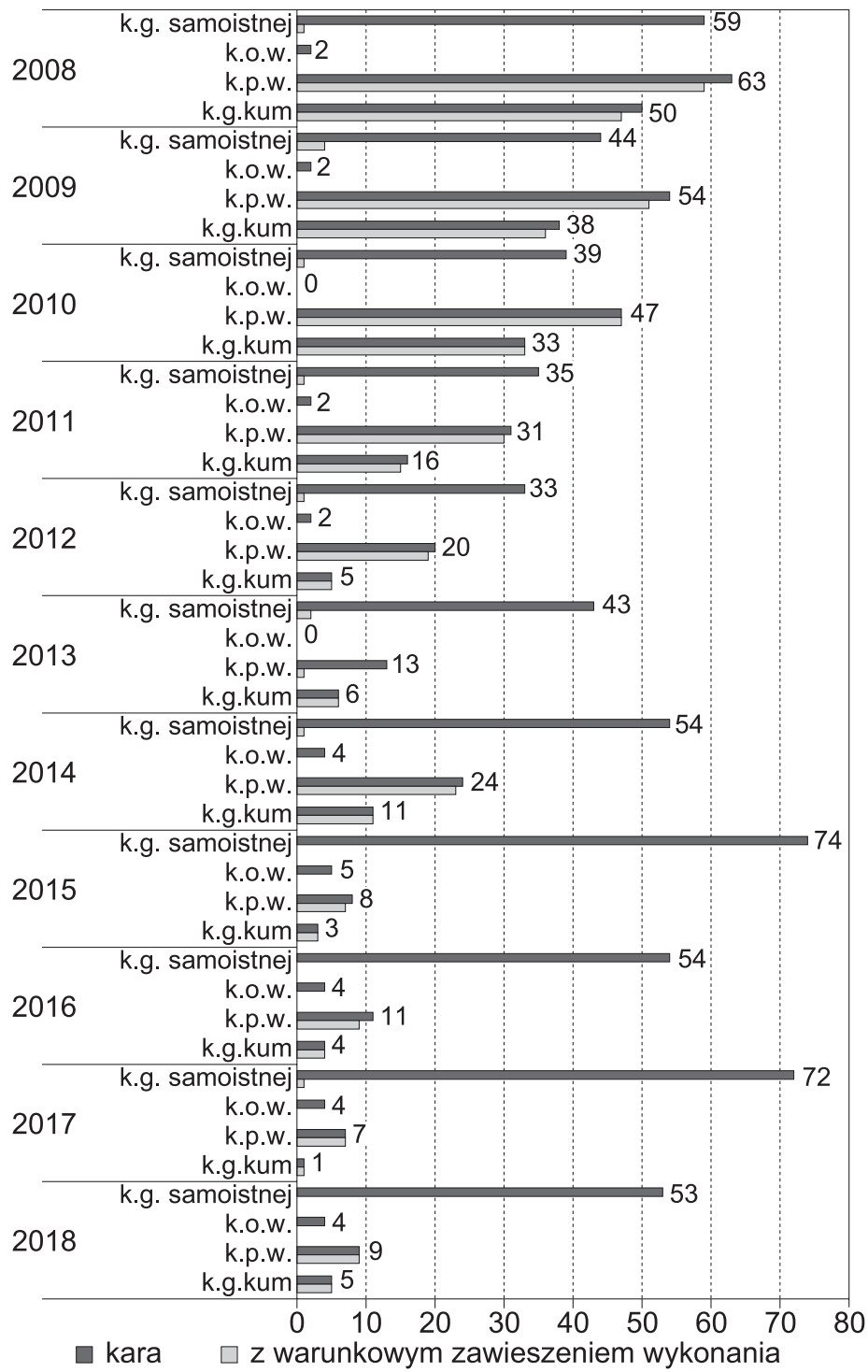

Wykres 2. Struktura kar orzeczonych za przestępstwa stypizowane w k.s.h. w latach 2008-2018 Źródło: opracowanie własne. 
gdy w początkowych latach badanego okresu (lata 2008-2010) w strukturze orzekanych kar dominuje kara pozbawienia wolności z warunkowym zawieszeniem jej wykonania ${ }^{53}$, od 2011 roku udział kary pozbawienia wolności w strukturze kar orzekanych za przestępstwa z k.s.h. wyraźnie maleje. Przyczyną takiego stanu rzeczy jest, po pierwsze, uchylenie przepisu art. 585 k.s.h. i zmniejszanie się liczby skazań za przestępstwo działania na szkodę spółki (od 2014 roku skazania za to przestępstwo nie występują), za które to kara pozbawienia wolności w większości wypadków była orzekana. Po drugie, wpływ na taki stan rzeczy niewątpliwie mają także zmiany przeprowadzone w prawie karnym w 2015 roku, modyfikujące dotychczasowy system karania ${ }^{54}$. Zapewnieniu realizacji tego celu miało służyć ograniczenie szerokiego stosowania kary pozbawienia wolności wraz z warunkowym zawieszeniem jej wykonania na rzecz efektywnego stosowania kar wolnościowych, takich jak kara grzywny czy kara ograniczenia wolności ${ }^{55}$. Obecnie w strukturze skazań osób dorosłych za przestępstwa stypizowane w k.s.h. dominuje kara grzywny samoistnej (w 2018 roku — 53 przypadki). Kara pozbawienia wolności stosowana jest wyjątkowo i przeważnie z warunkowym zawieszeniem jej wykonania (w 2018 roku - 9 przypadków, wszystkie z warunkowym zawieszeniem wykonania). Oprócz tak orzekanej kary niekiedy wymierzana jest kara grzywny kumulatywnej, jednakże również z warunkowym zawieszeniem jej wykonania (w 2018 roku -5 przypadków, wszystkie z warunkowym zawieszeniem wykonania). W badanym czasie do kary ograniczenia wolności sięgano niezmiernie rzadko. W ostatnich latach (2016-2018) kara ograniczenia wolności była stosowana w 4 przypadkach rocznie.

Aktualna tendencja w zakresie karania za przestępstwa stypizowane w k.s.h. wyraża się w uczynieniu z kary grzywny samoistnej głównego instrumentu zwalczania patologii w sferze funkcjonowania spółek han-

53 Taki stan rzeczy był zbieżny z ogólnymi tendencjami karania za przestępstwa gospodarcze. Zob. P. Ochman, Selected issues of penalisation in penal economic law. Remarks on the crimes against economic circulation (Chapter XXXVI of Criminal Code), „Nowa Kodyfikacja Prawa Karnego” 42, 2016, s. 89-91.

54 Ustawa z dnia 20 lutego 2015 roku o zmianie ustawy — Kodeks karny oraz niektórych innych ustaw (Dz.U. z 2015 r. poz. 396 z późn. zm.).

55 Zob. J. Majewski, Kodeks karny. Komentarz do zmian 2015, Warszawa 2015, s. 53. 


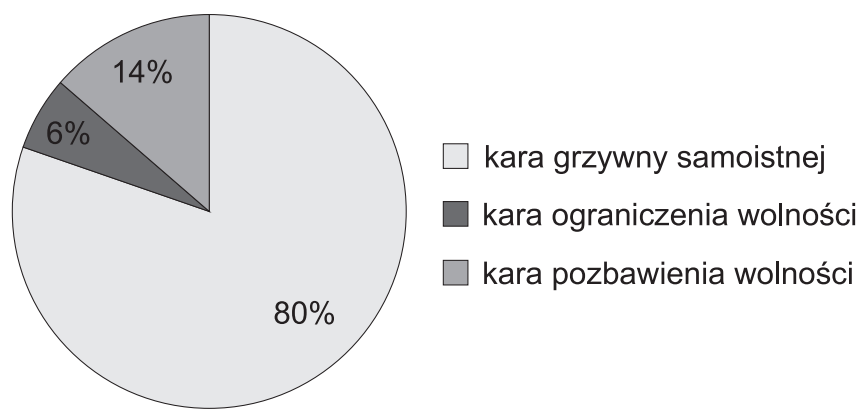

Wykres 3. Struktura kar orzekanych za przestępstwa stypizowane w k.s.h. w 2018 roku

Źródło: opracowanie własne.

dlowych. Wyłącznie posiłkowo wykorzystywana jest kara pozbawienia wolności, oprócz której często wymierzana jest kara grzywny, przy czym wykonanie tych kar najczęściej jest warunkowo zawieszane. Z uwagi na kształt sankcji karnych za przestępstwa stypizowane w k.s.h. nie jest stosowana tak zwana sankcja mieszana. Zasądzanie natomiast kary ograniczenia wolności jest w tym wypadku zupełnie marginalne. Taki stan rzeczy stanowi realizację postulatów zawartych w wydanych ponad trzydzieści lat temu Zaleceniach Rady Europy dotyczących przestępstw gospodarczych $^{56}$. Wskazano wówczas, że zasada ultima ratio $\mathrm{w}$ sferze penalizacji działalności gospodarczej powinna dotyczyć również wyboru rodzaju kary. Celem karania w tej sferze powinno być bowiem odstraszenie potencjalnego sprawcy. W konsekwencji należy sięgać po kary pozbawienia wolności wyłącznie w przypadku poważnych występków, a także zapewnić odzwierciedlenie w wymiarze kary grzywny sytuacji finansowej sprawcy oraz wagi popełnionego przestępstwa ${ }^{57}$.

5. Analizując wymiar kary pozbawienia wolności stosowanej wobec sprawców przestępstw stypizowanych w k.s.h. w latach 2008-2018, należy wskazać, że w znacznej mierze stosowana jest ona z warunkowym zawieszeniem jej wykonania. Przypadki, w których nie jest wykorzystywany ten środek probacyjny, są marginalne.

56 Recommendation No. R (81) 12 of The Committee of Ministers to Member States on Economic Crime, Strasbourg 1981.

57 Ibidem. 
Tabela 3. Kara pozbawienia wolności orzekana za przestępstwa stypizowane w k.s.h. w latach 2008-2018

\begin{tabular}{|l|c|c|c|c|c|c|c|c|c|c|c|}
\hline & 2008 & 2009 & 2010 & 2011 & 2012 & 2013 & 2014 & 2015 & 2016 & 2017 & 2018 \\
\hline Ogółem & 63 & 54 & 47 & 31 & 20 & 13 & 24 & 8 & 11 & 7 & 9 \\
\hline $\begin{array}{l}\text { Bez } \\
\text { zawieszenia }\end{array}$ & 4 & 3 & 0 & 1 & 1 & 1 & 1 & 1 & 2 & 0 & 0 \\
\hline
\end{tabular}

Źródło: opracowanie własne.

Taki stan rzeczy ma jednak wady, gdyż powoduje, że w istocie sprawca fizycznie nie odczuwa istotnej dolegliwości związanej z wykonaniem takiej kary. Okoliczność ta jest co prawda minimalizowana przez fakt, iż prawomocne skazanie za przestępstwa stypizowane w k.s.h. powoduje zaktualizowanie się zakazu pełnienia funkcji piastuna organu

Tabela 4. Struktura kary pozbawienia wolności orzekanej za przestępstwa stypizowane w k.s.h. w latach 2008-2018

\begin{tabular}{|l|c|c|c|c|c|c|c|c|c|}
\hline & $\begin{array}{c}<1 \\
\text { mies. }\end{array}$ & $\begin{array}{c}1 \\
\text { mies. }\end{array}$ & $\begin{array}{c}2 \\
\text { mies. }\end{array}$ & $\begin{array}{c}3 \\
\text { mies. }\end{array}$ & $\begin{array}{c}4-5 \\
\text { mies. }\end{array}$ & 6 mies. & $\begin{array}{c}7-11 \\
\text { mies. }\end{array}$ & 1 rok & $\begin{array}{c}>1 \\
\text { rok- } \\
<2 \text { lata }\end{array}$ \\
\hline 2008 & 0 & 1 & 8 & $7 *$ & $13^{*}$ & $12^{*}$ & 13 & $9^{*}$ & 0 \\
\hline 2009 & 0 & 2 & 1 & 7 & $11^{*}$ & 16 & $11^{*}$ & 5 & $1 *$ \\
\hline 2010 & 0 & 0 & 7 & 6 & 17 & 4 & 8 & 3 & 2 \\
\hline 2011 & 4 & 0 & 3 & $6 *$ & 5 & 5 & 6 & 1 & 1 \\
\hline 2012 & 0 & 1 & $4 *$ & 6 & 5 & 1 & 1 & 1 & 1 \\
\hline 2013 & 0 & 0 & 1 & 0 & $8^{*}$ & 3 & 0 & 0 & 1 \\
\hline 2014 & 0 & 0 & 0 & 10 & $6^{*}$ & 4 & 3 & 1 & 0 \\
\hline 2015 & 0 & 0 & 1 & 3 & 0 & 2 & $1 *$ & 1 & 0 \\
\hline 2016 & 0 & 0 & 0 & 1 & 1 & $7 * *$ & 2 & 0 & 0 \\
\hline 2017 & 0 & 0 & 3 & 1 & 1 & 2 & 0 & 0 & 0 \\
\hline 2018 & 0 & 0 & 1 & 4 & 1 & 1 & 2 & 0 & 0 \\
\hline
\end{tabular}

* w jednym przypadku bez warunkowego zawieszenia wykonania kary ** w dwóch przypadkach bez warunkowego zawieszenia wykonania kary

Źródło: opracowanie własne. 
w spółkach handlowych określony w art. $18 \S 2$ k.s.h. ${ }^{58}$ Niemniej jednak niezdolność pełnienia funkcji piastuna organu w spółkach handlowych nie musi w każdym wypadku stwarzać dolegliwość dla sprawcy przestępstwa gospodarczego.

Za przestępstwa stypizowane w k.s.h. kara pozbawienia wolności w latach 2008-2019 była wymierzana w wysokości nieprzekraczającej dwóch lat. Oprócz kary pozbawienia wolności wymierzana była kara grzywny kumulatywnej, zazwyczaj z warunkowym zawieszeniem jej wykonania. Wysokość tej kary rzadko jednak przekraczała 5000 złotych. Warto wskazać, że w ostatnich latach odsetek prawomocnych skazań za przestępstwa z k.s.h. przy wykorzystaniu wskazanego modelu karania maleje.

Tabela 5. Kara grzywny orzekana obok kary pozbawienia wolności za przestępstwa stypizowane w k.s.h. w latach 2008-2018

\begin{tabular}{|l|c|c|c|c|c|c|c|c|c|c|c|}
\hline & 2008 & 2009 & 2010 & 2011 & 2012 & 2013 & 2014 & 2015 & 2016 & 2017 & 2018 \\
\hline $\begin{array}{l}\text { Kara pozbawienia } \\
\text { wolności }\end{array}$ & 63 & 54 & 47 & 31 & 20 & 13 & 24 & 8 & 11 & 7 & 9 \\
\hline $\begin{array}{l}\text { Kara grzywny } \\
\text { kumulatywnej }\end{array}$ & 50 & 38 & 33 & 16 & 5 & 6 & 11 & 3 & 4 & 1 & 5 \\
\hline
\end{tabular}

Źródło: opracowanie własne.

5. Analizując wymiar grzywny samoistnej stosowanej wobec sprawców przestępstw stypizowanych w k.s.h. w latach 2008-2018, należy wskazać, że kara ta staje się zasadniczym instrumentem represji przeciwko patologiom w funkcjonowaniu spółek handlowych. Niemniej jednak stosunkowo rzadko wymierzana jest ona w wysokości powyżej 5000 złotych, co w świetle jej rozpiętości sięgającej od 100 do 1080000 złotych czyni ją karą raczej symboliczną. Warto mimo tego wskazać, iż ograniczenie w tym zakresie ustanawia przepis art. $33 \S 3$ Kodeksu karnego, określający zasady wymiaru kary grzywny. Szczegółowy stan w zakresie wymiaru tej kary w latach 2008-2018 za przestępstwa stypizowane w k.s.h. przedstawia tabela 7.

58 Zob. szerzej P. Ochman, Z problematyki zakazu petnienia funkcji piastuna organu w spółkach handlowych - uwagi na marginesie przepisu art. 18 \& k.s.h., „Rejent” 2012, nr 12, s. 69-96. 
Tabela 6. Struktura kary grzywny kumulatywnej orzekanej za przestępstwa stypizowane w k.s.h. w latach 2008-2018

\begin{tabular}{|c|c|c|c|c|c|c|c|c|c|c|}
\hline & $\begin{array}{l}\bar{N} \\
\stackrel{\Xi}{ } \\
\vec{V}\end{array}$ & $\begin{array}{l}\bar{N} \\
\stackrel{0}{0} \\
\stackrel{1}{1} \\
\stackrel{0}{0}\end{array}$ & $\begin{array}{l}\bar{N} \\
8 \\
8 \\
i \\
\frac{1}{0}\end{array}$ & $\begin{array}{l}\bar{N} \\
8 \\
\stackrel{1}{1} \\
\frac{1}{8} \\
\end{array}$ & $\begin{array}{l}\bar{N} \\
8 \\
\infty \\
1 \\
\frac{1}{0} \\
י\end{array}$ & $\begin{array}{l}\bar{N} \\
8 \\
8 \\
\frac{1}{8} \\
\stackrel{\infty}{\infty}\end{array}$ & $\begin{array}{l}\bar{N} \\
8 \\
0 \\
\stackrel{1}{1} \\
\stackrel{8}{0}\end{array}$ & $\begin{array}{l}\bar{N} \\
8 \\
0 \\
i \\
i \\
0 \\
0\end{array}$ & 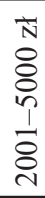 & $\begin{array}{l}\bar{N} \\
8 \\
8 \\
\wedge \\
\wedge\end{array}$ \\
\hline 2008 & 0 & 0 & 3 & 3 & 7* & $6^{*}$ & 2 & 6 & 17 & $6^{*}$ \\
\hline 2009 & $1 *$ & 1 & 0 & $6^{*}$ & 4 & 8 & 1 & 6 & 5 & 6 \\
\hline 2010 & 1 & 1 & 1 & 3 & 0 & 10 & 0 & 5 & 8 & 4 \\
\hline 2011 & 0 & 0 & 1 & 1* & 1 & 6 & 1 & 1 & 1 & 4 \\
\hline 2012 & 0 & 0 & 0 & 0 & 0 & 1 & 0 & 1 & 0 & 3 \\
\hline 2013 & 0 & 0 & 0 & 0 & 0 & 0 & 1 & 0 & 4 & 1 \\
\hline 2014 & 1 & 0 & 0 & 2 & 2 & 0 & 0 & 4 & 2 & 0 \\
\hline 2015 & 0 & 0 & 0 & 1 & 0 & 1 & 0 & 1 & 0 & 0 \\
\hline 2016 & 0 & 0 & 0 & 0 & 1 & 0 & 0 & 2 & 1 & 0 \\
\hline 2017 & 0 & 0 & 0 & 0 & 1 & 0 & 0 & 0 & 0 & 0 \\
\hline 2018 & 0 & 0 & 0 & 1 & 0 & 0 & 0 & 0 & 2 & 2 \\
\hline
\end{tabular}

* w jednym przypadku bez warunkowego zawieszenia wykonania kary

Źródło: opracowanie własne.

Tabela 7. Struktura kary grzywny orzekanej za przestępstwa stypizowane w k.s.h. w latach 2008-2018

\begin{tabular}{|c|c|c|c|c|c|c|c|c|c|}
\hline & $\begin{array}{l}\bar{N} \\
\stackrel{2}{0} \\
\text { 1 } \\
\stackrel{0}{0}\end{array}$ & 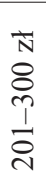 & $\begin{array}{l}\bar{N} \\
8 \\
0 \\
i \\
\frac{1}{0} \\
\end{array}$ & $\begin{array}{l}\bar{N} \\
8 \\
\infty \\
1 \\
i \\
i\end{array}$ & $\begin{array}{l}\bar{N} \\
8 \\
8 \\
\frac{1}{8} \\
\frac{1}{\infty}\end{array}$ & $\begin{array}{l}\bar{N} \\
8 \\
0 \\
\stackrel{1}{1} \\
8 \\
0\end{array}$ & 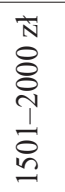 & 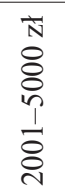 & $\begin{array}{l}\bar{N} \\
8 \\
8 \\
\wedge \\
\wedge\end{array}$ \\
\hline 2008 & 0 & 0 & 2 & 6 & 15 & 8 & $13^{*}$ & 12 & 3 \\
\hline 2009 & 0 & 0 & 1 & 5 & $10 *$ & 8* & 2 & 14 & $4 * *$ \\
\hline 2010 & 0 & 0 & 1 & 2 & 6 & 10 & $11^{*}$ & 7 & 2 \\
\hline 2011 & 0 & 0 & 0 & 3 & 6 & 3 & 11 & $9 *$ & 3 \\
\hline 2012 & $1 *$ & 0 & 1 & 1 & 8 & 6 & 3 & 11 & 2 \\
\hline 2013 & 0 & 0 & 2 & 6 & $10^{*}$ & 4 & 5 & $13 *$ & 3 \\
\hline 2014 & 1 & 1 & 0 & 5 & 12 & 7 & 9 & $12^{*}$ & 7 \\
\hline
\end{tabular}




\begin{tabular}{|c|c|c|c|c|c|c|c|c|c|}
\hline 2015 & 0 & 1 & 3 & 7 & 9 & 17 & 17 & 16 & 4 \\
\hline 2016 & 0 & 0 & 4 & 7 & 10 & 1 & 10 & 19 & 3 \\
\hline 2017 & 0 & 1 & 3 & 0 & 14 & 7 & $14^{*}$ & 28 & 5 \\
\hline 2018 & 0 & 1 & 0 & 3 & 7 & 7 & 5 & 21 & 9 \\
\hline
\end{tabular}

* w jednym przypadku z zastosowaniem warunkowego zawieszenia wykonania kary ** w dwóch przypadkach z zastosowaniem warunkowego zawieszenia wykonania kary

Źródło: opracowanie własne.

\section{Podsumowanie}

1. Prawomocne skazania za przestępstwa stypizowane w k.s.h. nie są często spotykane w praktyce wymiaru sprawiedliwości. Jest to przejaw ogólniejszej tendencji dotyczącej występowania w praktyce organów ścigania i organów wymiaru sprawiedliwości pozakodeksowych przestępstw gospodarczych ${ }^{59}$.

2. Niewątpliwie przestępstwa stypizowane w k.s.h. mają za zadanie ochronę prawidłowego funkcjonowania spółek handlowych, a kształt ich ustawowych znamion został wypracowany niejako drogą ewolucyjną. Biorąc jednak pod uwagę liczbę skazań prezentowanych w danych statystycznych za przestępstwa z k.s.h., należy uznać, iż nie mogą one stanowić podstawy do czynienia szerszych uogólnień w zakresie karania za przestępstwa gospodarcze w ogóle.

3. Obecna polityka karna stosowana przez sądy wobec sprawców tych przestępstw jest zasadniczo prawidłowa. Główną karą nakładaną w tym zakresie jest bowiem kara grzywny samoistnej, niekiedy stosowana jest również kara pozbawienia wolności. Można wyrazić jedynie wątpliwość, czy nie byłoby możliwe częstsze sięganie po karę ograniczenia wolności ${ }^{60}$. Jakiekolwiek stanowcze wypowiedzi w tym zakresie wymagałyby jednak uprzedniego przeprowadzenia rzetelnych badań aktowych. Ze względu na brak pogłębionych badań w zakresie postępowań przygo-

59 Zob. T. Szymanowski, op. cit., s. 23.

60 Zob. P. Ochman, Z problematyki kary ograniczenia wolności w prawie karnym gospodarczym (uwagi na marginesie przestepstw przeciwko obrotowi gospodarczemu), [w:] A. Kwieciński, Teoretyczne i praktyczne aspekty wykonywania kary ograniczenia wolności, Wrocław 2016, s. 93-103. 
towawczych w sprawach o przestępstwa stypizowane w k.s.h. (zwłaszcza w zakresie przyczyn umorzeń oraz odmów wszczęcia postępowania) przedwczesny jest również wniosek o zbędności tych przestępstw w systemie pozakodeksowego prawa karnego gospodarczego.

\section{Bibliografia}

Babbie E., Podstawy badań społecznych, Warszawa 2013.

Bieniak J., Bieniak M., Nita-Jagielski G., Kodeks spótek handlowych. Komentarz, Warszawa 2017.

Biuletyn z posiedzenia Komisji Nadzwyczajnej do Spraw Zmian w Kodyfikacjach, Warszawa 2011.

Błachnio-Parzych A., Zbieg odpowiedzialności karnej i administracyjno-karnej jako zbieg reżimów odpowiedzialności represyjnej, Warszawa 2016.

Błachut J., Problemy zwiazane z pomiarem przestępczości, Warszawa 2007.

Bogomilska-Król M., Zastosowanie konwencyjnych standardów praw do naruszeń penalizowanych $w$ prawie krajowym niemajacych ściśle prawnokarnego charakteru - glosa do uchwaty Sadu Najwyższego z 27.08.2015 r., III CZP 62/15, dotyczacej naruszenia z art. 594 k.s.h., „Europejski Przegląd Sądowy” 2018, nr 8.

Bojarski M., Radecki W., Pozakodeksowe prawo karne. Komentarz, t. 2, Warszawa 2003.

Czapska J., Gaberle A., Światłowski A., Zoll A., Zasady procesu karnego wobec wyzwań wspótczesności. Księga pamiątkowa ku czci profesora Stanistawa Waltosia, Warszawa 2002.

Dermont A., Przestęstwa gospodarcze w kodeksie spótek handlowych - wybrane zagadnienia, „Prokuratura i Prawo” 2001, nr 10.

Giezek J., Kardas P., Przepisy karne kodeksu spótek handlowych, Kraków 2003.

Kardas P., Złożenie sadowi rejestrowemu listy wspólników niezgodnej z treścia wpisów w księdze udziatów, „Czasopismo Prawa Karnego i Nauk Penalnych” 2006, nr 1.

Kodeks spótek handlowych, red. A. Opalski, t. 4. Łączenie, podziat i przekształcanie spótek. Przepisy karne. Komentarz. Art. 491-633, Warszawa 2016.

Kwieciński A., Teoretyczne i praktyczne aspekty wykonywania kary ograniczenia wolności, Wrocław 2016.

Majewski J., Kodeks karny. Komentarz do zmian 2015, Warszawa 2015.

Ochman P., Ochrona działalności bankowej w prawie karnym gospodarczym. Przepisy karne ustaw bankowych, Warszawa 2011.

Ochman P., Selected issues of penalisation in penal economic law. Remarks on the crimes against economic circulation (Chapter XXXVI of Criminal Code), „Nowa Kodyfikacja Prawa Karnego" 42, 2016.

Ochman P., Z problematyki zakazu petnienia funkcji piastuna organu w spótkach handlowych - uwagi na marginesie przepisu art. 18 \& 2 k.s.h., „Rejent” 2012, nr 12. 
Prawomocne skazania osób dorosłych w latach 1946-2016, Warszawa 2017, https:// isws.ms.gov.pl/pl/baza-statystyczna/publikacje/download,2779,9.html (dostęp: 3.11.2019).

Prawomocnie skazani dorośli według rodzajów przestępstw $i$ wymiaru kary, https://isws. ms.gov.pl/pl/baza-statystyczna/opracowania-wieloletnie/download,2853,40.html (dostęp: 3.11.2019).

Rocznik Statystyczny Rzeczypospolitej Polskiej, Warszawa 2018.

Rogala M., Spółki osobowe a przepisy karne kodeksu spółek handlowych, „Prawo Spółek" 2001, nr 1.

Siemiątkowski T., Potrzeszcz R., Kodeks spólek handlowych. Komentarz, t. 4, Warszawa 2011.

Sołtysiński S., Szajkowski A., Szumański A., Szwaja J., Kodeks spółek handlowych, t. 4. Łączenie, podziat i przekształcanie spółek. Przepisy karne. Komentarz do artykułów 491-633, Warszawa 2012.

Szymanowski T., Zmiany w przestępczości w Polsce $w$ okresie po odzyskaniu niepodległości oraz ewolucja polityki karnej w tym okresie $w$ świetle danych statystycznych, „Rejent” 2018, nr 9.

Zawłocki R., Czy przepisy karne w Kodeksie spółek handlowych sa potrzebne, „Monitor Prawa Handlowego" 2013, nr 1.

Zawłocki R., Nowe przestęstwo niegospodarności bezszkodowej z art. 296 § 1a KK, „Monitor Prawniczy” 2011, nr 18.

Zawłocki R., System Prawa Karnego, t. 9. Przestęstwa przeciwko mieniu i gospodarcze, Warszawa 2011.

Żółtek S., Prawo karne gospodarcze w aspekcie zasady subsydiarności, Warszawa 2009.

\title{
Economic offenses under the Commercial Companies Code in the light of statistical data
}

\author{
Summary
}

The aim of the article is to analyze convictions of adults for economic crimes in the Commercial Companies Code. The analysis concerns both the structure of convictions and their dynamics in the field of convictions in general, as well as the structure of punishments for crimes. An attempt is also made to explain the trends in this area.

Keywords: economic crime, penal economic law, commercial code, statistical data. 